\title{
Studi Perbandingan Konflik Pers Indonesia dan Pers Malaysia dalam Konteks Nationality of Press dan Neighbor's Press
}

\author{
Fiandy Mauliansyah \\ Program Studi Ilmu Komunikasi, Universitas Teuku Umar \\ Email: fiandymauliansyah@gmail.com
}

\begin{abstract}
This paper aim to examine on a comparison between press freedom in Indonesia and Malaysia in proclaiming their relationship. This study is expected to explain more about the difference that the author seems to differences over the rationality and public opinion. In this study, it was found that freedom of the press in the context of "neighboring countries" on the one side can be a fire in the hull that is tangible to the bilateral conflict so that each lost principle of balancing of the press. But on the other side, freedom of the press, however-more realiable in rationality and acceptance of public opinion, the similarities and differences are quite acceptable.
\end{abstract}

Keywords: Freedom of the Press. Neighbor's Press. Rasionality and Public Opinion

\section{PENDAHULUAN}

Dalam kehidupan masyarakat, perbedaan dan persamaan pandangan merupakan bentuk dari sebuah kewajaran dalam berkehidupan. Hal ini juga berlaku dalam tubuh media massa, termasuk pers di negara-negara yang meskipun secara geografis sangat berdekatan. Dalam tingkatan tertentu, pers di negara-negara Asia Tenggara bisa memberikan yang sama terhadap sebuah peristiwa yang terjadi pada salah satu negara anggota ASEAN (Haryatmoko, 2007). Di sisi lain, meskipun Indonesia dan Malaysia memiliki kedekatan geografis, pers di kedua negara ini bisa memberikan pandangan yang bertolak belakang.

Seperti yang diketahui, pada masa Orde Baru sebelum 1998, pers di Indonesia senantiasa mendapat tekanan dan kontrol yang ketat dari pemerintah. Sementara pada Era Reformasi telah dirumuskan undang-undang baru yang menjamin kemerdekaan bagi insan pers. Pemerintah Indonesia memberikan kebebasan pers yang tidak dalam kontrol pemerintah tetapi masih tertakluk kepada Kode Etik Jurnalistik. Pada masa yang sama, Malaysia -selaku negara tetangga- masih mengontrol pers karena dalam proses membangun negara, kestabilan sangat diperlukan supaya tidak terganggu oleh usaha-usaha yang dapat menganggu pembangunan. Kebebasan pers yang wujud di Malaysia adalah kebebasan yang berada dalam peraturan perundang-undangan (Hasim, 2005). Hal ini untuk mencegah supaya tidak tersebar berita yang dapat menggugat kestabilan negara. 
Setelah memasuki Era Reformasi banyak peristiwa yang telah menimbulkan perselisihan antara dua negara. Sejak itu, golongan media berlomba-lomba menulis tentang isu sensitif yang berpotensi mengeruhkan hubungan bilateral. Peristiwa-peristiwa yang terjadi dalam beberapa tahun ke belakang telah menjadi fokus utama pihak media. Hal ini terbukti dari perhatian yang diberikan oleh kedua pers terhadap operasi penangkapan serta pemulangan pendatang tanpa izin (PATI). Selain itu, pers juga mempublikasikan berita tentang sikap beberapa majikan Malaysia yang cenderung tidak manusiawi terhadap pekerja Indonesia.

Keadaan bertambah buruk ketika media Malaysia melaporkan keluhan masyarakatnya terhadap berbagai masalah sosial dan kriminal yang ditimbulkan oleh pendatang tanpa izin yang berasal dari Indonesia, kabut asap yang diakibatkan oleh kebakaran hutan di Sumatera dan Kalimantan dan perang dunia "maya" yang terjadi di new media. Paparan berita mengenai Malaysia-Indonesia terdiri dari berbagai topik seperti politik, ekonomi, sosial, budaya dan lingkungan. Salah satu isu yang menjadi sorotan pers ialah sengketa wilayah Sipadan-Ligitan dan Ambalat. Isu ini merupakan isu politik tentang wilayah yang berada di perbatasan kedua negara. Isu Sipadan-Ligitan merupakan isu perbatasan pertama yang muncul di pers kedua negara setelah Indonesia menggulingkan pemerintahan Orde Baru. Sengketa Sipadan-Ligitan merupakan perselisihan antara Malaysia dan Indonesia atas kepemilikan dua pulau yang berada di Selat Makassar. Pada 13 Januari 2003, berita yang berjudul "Penyelesaian Sengketa Sipadan-Ligitan Interpelasi" dipaparkan oleh Kompas. Dua tahun setelah itu, Ambalat menjadi fokus utama pihak pers. Wajarlah jika hubungan semakin keruh dan perasaan-perasaan emosional menjalar dalam jiwa masyarakat di dua negara. Dilanjutkan pula dengan perang blog yang terjadi di internet (www.topix.com/forum/world/malaysia). Perang dunia maya tersebut menggunakan kata-kata yang kasar bahkan kadang merusak website pihak-pihak tertentu (detikinet, 31 Ogos 2007).

Tulisan ini mencoba mengkaji tentang kebebasan pers di Indonesia dan Pers Negara Tetangga (Malaysia) dalam konteks negara bertetangga dalam mewartakan hubungan mereka. Sehingga kajian ini diharapkan mampu menjelaskan tentang perbedaan tersebut yang menurut penulis sepertinya perbedaan yang ada lebih kepada rasionalitas dan opini publik..

\section{KAJIAN TEORITIS}

\section{Sistem Media; Empat Teori Pers}

Suatu karya klasik dalam bidang teori pers selama ini, yaitu Four Theories of the Press, karangan Siebert, Peterson dan Schramm (1956) telah menciptakan paradigma dominan dalam menganalisis sistem-sistem media di dunia, khususnya dalam menilai tingkat kebebasan pers di berbagai negara dan wilayah dunia. Sekalipun kemudian muncul teori-teori pers sesudahnya, seperti jurnalisme pembangunan, media revolusioner dan media demokratik-partisipan, tetapi teori-teori itu hanya merupakan pelengkap dari empat teori dasar yang sudah mapan sebelumnya (McQuail, 2000). Sistem otoriter mengatur media untuk mendukung dan memajukan kebijakan pemerintah demi pencapaian tujuannya (Siebert, dalam McQuail. 1997). Masalah yang paling utama dalam sistem ini adalah membuat serta melaksanakan pengawasan efektif terhadap media, terutama yang dimiliki swasta. Mekanisme kontrol yang dijalankan antara lain sistem perizinan, sensor oleh pemerintah, pajak khusus, undang-undang dan peraturan, yang tujuannya untuk mempertahankan bangsa dan negara dari pengkhianatan dan makar. Menurut Siebert et al, penganut sistem otoriter tidak mempersoalkan atau menolak diskusi tentang system politik secara filsafati umum, namun tidak memperbolehkan kritik 
langsung terhadap pemimpinpemimpin politik yang sedang berkuasa, maupun kebijaksanaan dan proyek pemerintahan yang dilaksanakannya, apalagi upaya-upaya terbuka untuk menggulingkan kekekuasaan.

Konsep pers Otoriter didasarkan pada sejarah dan falsafah abad 16 dan 17 di Inggris tentang kekuasaan absolut kerajaan. Sebaliknya, teori Libertarian berpandangan bahwa orang adalah makhluk yang rasional dan memiliki tujuan hidupnya sendiri. Kebahagiaan dan kesejahteraanindividu merupakan tujuan dari masyarakat. Masa pencerahan di Eropa telah memberi dorongan pada pencetusan konsep libertarian, dengan tuntutannya untuk membebaskan manusia dari segala pembatasan di luar dirinya untuk pencapaian tujuannya sendiri (Siebert et al, 1954). Nama-nama seperti John Milton, John Stuart Mill dan Thomas Jefferson merupakan pemikir-pemikir besar di belakang konsep ini.

Fungsi dari media libertarian adalah untuk memberi informasi dan hiburan, serta bertindak sebagai penjaga (watchdog) terhadap pemerintah. Media libertarian kebanyakan milik swasta. Kontrol terhadap media Libertarian kebanyakan dilakukan melalui proses "pembenaran-sendiri" (self-righting process) dan pengadilan, sekalipun perizinan, sensor atau perampasan materi penghinaan dan penghentian publikasi suratkabar juga kadang-kadang digunakan. Sensor sukarela juga kadang-kadang dipraktekkan, sementara hak untuk mendapat akses kepada sumbersumber pemerintahan pun dituntut secara aktif.

Teori Tanggung Jawab Sosial merupakan perkembangan lebih lanjut dari teori Libertarian dan pertama kali dicetuskan pada abad 20 di Amerika Serikat oleh Komisi Kebebasan Pers, yang menekankan pada tanggung jawab sosial pers di samping kebebasan yang dimilikinya. Di samping fungsinya untuk memberikan informasi, menghibur dan menjual, pers berkewajiban juga untuk "mengangkat konflik ke ranah diskusi" (Severin dan Tankard, 2001). Kontrol terhadap pers kebanyakan dalam bentuk pendapat publik, tindakan konsumen dan etika profesi. Perbedaan pokok antara teori Libertarian dan teori Tanggung Jawab Sosial adalah bahwa teori Tanggung Jawab Sosial menyarankan perlunya media dijaga oleh suatu lembaga agar bekerja secara bertanggung jawab, apabila mereka tidak melaksanakannya secara sukarela.

Teori Komunis (Soviet) berlandaskan pada ideology Marxis dan menilai tinggi kesatuan, yaitu kesatuan kelas pekerja dan kesatuan partai. Demi kesatuan, hanya ada satu posisi yang benar dan hanya satu kebenaran, yakni kebenaran absolut. Peranan dari pers adalah untuk menginterpretasikan doktrin dan untuk melaksanakan kebijakan-kebijakan partai. Media dalam masyarakat komunis dimiliki negara dan harus menjadi "propagandis kolektif, pengobar semangat kolektif- dan penata kolektif. Motif keuntungan dihilangkan dari kegiatan penerbitan dan penyiaran. Pemerintah memiliki suatu divisi khusus untuk penyensoran pers. Cara pengontrolan lain adalah penunjukan editor, arahanarahan yang banyak tentang isi media, tajuk dan kritik media. Keempat teori pers tradisional tersebut kiranya masih dapat digunakan sebagai pisau analisis bagi kajian tentang pers suatu Negara. Dalam perjalanannya, pembagian keempat teori itu mendapatkan kritikan, bahkan ada yang menyarankan pendapat bahwa teoriteori dominan itu tidak dapat secara memuaskan mendeskripsikan realitas media di berbagai negara.

\section{Kebebasan Pers: Perspektif Dunia}

Sistem pers sebuah negara dibentuk oleh keadaan politik negara tersebut (Lihat Mancini dan Hallin, 2004; Hazel, 2001; Hardt, 1997) . Sistem ini berlandaskan sistem pemerintahan, politik, undang-undang, nilai budaya dan sejarah negara itu. Selain itu, 
keanekeragaman etnis, agama, dan bahasa turut memainkan peranan penting dalam pembentukan sistem pers tersebut (Hardt, 1988). Sistem pers yang telah disepakati ini akan berpengaruh kepada kebebasan pers (Safar Hasim, 1996).

Dari Indeks Kebebasan Pers 2014, Malaysia berada di posisi ke-147 sedangkan Indonesia berada di posisi 132 dari 180 negara. Rating ini diberikan oleh Reporters Sans Frontières yang berlokasi di Paris, Perancis. RSF telah memantau kebebasan pers di seluruh dunia sejak tahun 1985. Semakin tinggi indeks suatu negara, semakin banyak kekangan terhadap kebebasan pers di negara itu.

Indeks kebebasan pers ini mengukur tingkat kebebasan pers di dunia yang menggambarkan tahap kebebasan yang dinikmati oleh wartawan dan organisasi media di suatu negara. Selain itu, indeks ini juga memperhitungkan usaha pemerintah dalam menghormati kebebasan bersuara. Pada tahun 2006, Malaysia memiliki indeks kebebasan pers yang rendah. Prestasi ini diperoleh ketika Malaysia dipimpin oleh Tun Abdullah Ahmad Badawi. Tan Sri Ramon Navaratman, Presiden Transparency International (Malaysia), mengatakan bahwa peningkatan dari segi pemahaman media adalah sesuatu yang membanggakan dan hal ini membuktikan bahwa pemerintah telah membuka ruang untuk berdiskusi dan berwacana (New Strait Times, 27 Oktober 2006).

Tidak seperti di Malaysia, perkembangan media khususnya pers di Indonesia telah melahirkan sistem dan organisasi pers baru. Perubahan ini berpengaruh terhadap pemberitaan mengenai hubungan Malaysia-Indonesia disebabkan kebebasan pers tanpa control (Lesmana, 2005). Pemimpin besar Malaysia dan Indonesia memaknai kebebasan pers dengan perspektif yang berbeda. Perdana Menteri Tun Dr. Mahathir Mohamad menulis dalam The New Straits Times pada 9 Juli 1981 dengan judul Freedom of the Press: Fact and Fallacy.

Dalam menjunjung kebebasan pers peranan potensi ini mesti diingat, selagi pers sedar (sadar) mengenai dirinya sebagai satu potensi ancaman kepada demokrasi dan secara baik menghadkan (membatasi) perlaksanaan hadnya, ia patut dibenarkan berfungsi tanpa gangguan pemerintah. Tetapi apabila pers dengan telah menyalahgunakan haknya dengan mengapi-apikan rakyat tanpa perlu, dalam keadaan itu pemerintah demokrasi patut mempunyai hak untuk mengontrolnya.

Presiden Republik Indonesia mempunyai pendapat yang berbeda terhadap kebebasan pers. Dalam pidato di Peringatan Hari Pers Nasional (HPN) pada 9 Februari, Presiden Susilo Bambang Yudhoyono meminta wartawan dan pakar media untuk melatih self-censorship (melakukan kontrol atas dirinya sendiri) karena zaman pemerintah mengontrol pers sudah berakhir. Kata beliau:

"Saya sangat ingin melihat "self censoring" diterapkan. Saya berharap para dewan press, wartawan senior, dan reporter dan pemimpin asosiasi wartawan akan menerapkan prinsip bagaimana menentukan apa yang sepatutnya diberitakan dan yang tidak patut diberitakan. Kebebasan press sangat dihargai di Indonesia sekarang dan Indonesia tidak akan kembali ke saat ketika pemerintah ikut campur dalam masalah media, tetapi kebebasan ini memiliki batasan sendiri. Kami mendukung kebebasan press, tetapi ketika kebebasan tersebut digunakan dengan baik dan bertanggungjawab".

(www.waspada.co.id) 
Kini, Indonesia-Malaysia telah menjalin hubungan selama 55 tahun. Sejauh ini, hubungan diplomatik antara kedua negara serumpun ini secara formal terjalin rukun, terutama di kalangan pemerintah. Namun di sebagian masyarakat terkadang masih muncul perselisihan yang berpontensi memicu konflik bilateral. Salah satu sumber dari masalah hubungan dua negara serumpun ini adalah pelaporan media di negara masing-masing yang menyuarakan perasaan tidak puas terhadap beberapa isu yang timbul.

Media merupakan platform untuk mengapresiasikan pemikiran yang lahir dari seluruh lapisan masyarakat. Abdul Latiff (2009) menyatakan dalam tulisannya, kebanyakan berita mengenai hubungan Malaysia-Indonesia hanya bersifat sensasional-provokatif, tidak berdasarkan kenyataan dan tindakan ini justru mampu mengeruhkan hubungan MalaysiaIndonesia. Apakah ini terjadi karena perbedaan indeks kebebasan pers yang pada akhirnya mampu mencorakkan berita tentang hubungan Malaysia-Indonesia?

\section{Self Censorship Media}

Pada tingkatan individual, self censorship merupakan rambu-rambu atau tanda-tanda dan juga konsep diri atau pilihan nilai seseorang dalam menghadapi berbagai masalah. Namun, pada tingkatan organisasi atau masyarakat, terlebih lagi media massa, self censorhip atau sensor diri adalah tindakan pengawasan yang dilakukan sendiri terutama dalam memenuhi berbagai kepentingan, yakni masyarakat dan pasar. Tindakan self censorship tidak hanya untuk menghadapi isu - isu sensitif, tapi juga dalam proses seleksi atau editing di media, kreativitas iklan, yang disebut juga soft censorship. Secara internal, media terus melakukan self censorship ini seperti pemilihan judul atau headline berita di surat kabar sebagai proses editing. Persoalanpersoalan yang timbul akibat pemberitaan di media menuntut perlunya self censorship. Dalam menghadapi tuntutan publik, media pun dengan kesadarannya (awareness) terus berupaya meningkatkan kualitas dengan cara menyensor isi media untuk mengurangi kontroversial atau untuk memenuhi selera publik dan industri. Para pemilik media khususnya, terus berusaha keras menerapkan self censorship secara sistematis dengan alasan kepentingan pasar. Meski dalam sistem pers liberal sekalipun, self censorship merupakan evidensi dalam proses seleksi (Chomsky \& Herman, 1994).

Hubungan antara media, masyarakat, dan pemerintah merupakan bentuk interlocking yang saling mengikat untuk menjadi satu sistem. Jika muncul ketidakpuasan masyarakat terhadap pers, maka muncullah bentuk protes atau keluhan, karena ada sistem yang saling mengunci tersebut. Dengan demikian, bentuk perlawanan atau keluhan dari masyarakat dan pemerintah terhadap isi media dalam komunikasi ketiga tingkatan tersebut. Banyak factor yang mempengaruhi isi media. Beberapa faktor intrinsik pada pekerja media yang dapat mempengaruhi isi media, pertama adalah karakteristik wartawan serta latar belakang personal dan profesional; kedua, sikap personal wartawan termasuk nilai-nilai dan keyakinannya serta ketiga orientasi profesional dan konsep peran. Selain level individual yang akan mempengaruhi isi media, juga ada pengaruh rutinitas media, organisasi media, eksternal media dan ideologi, yang semua merupakan bagian dalam proses self censorship itu sendiri (Shoemaker\&Reese, 2001).

Hubungan masing-masing level terhadap isi media pada hakikatnya merupakan refleksi sistem pers yang dipilih sebuah negara, sejalan dengan dengan sistem pemerintahannya. Di negara tersebut. Pada setiap sistem ini juga akan mencerminkan kebebasan pers yang dianut, serta bagaimana self censorship menjadi pegangan dalam melakukan kegiatan pers. Dalam sistem pers tanggungjawab sosial, misalnya, maka prinsip 
utama yang menjadi pegangan jurnalistik adalah: a) media seyogyanya menerima dan b) memenuhi dan menetapkan standar tinggi atau profesional media antara lain informatif, kebenaran, ketepatan, objektivitas dan keseimbangan, c) media seyogyanya dapat mengatur diri sendiri dalam kerangka hukum dan lembaga yang ada, d) menghindari hal yang dapat menimbulkan kejahatan, kerusakan, ketidaktertiban umum atau penghinaan terhadap minoritas etnik dan agama, e) mencerminkan kebinekaan masyarakat dan memberikan kesempatan sama untuk mengungkapkan berbagai sudut pandang dan hak jawab, f) masyarakat dan publik memiliki hak untuk standar profesi yang tinggi dan intervensi dapat dibenarkan untuk kepentingan umum, g) wartawan dan media profesional bertanggungjawab terhadap masyarakat, majikan dan pasar (McQuail, 2005: 234)

Prinsip-prinsip dalam sistem pers juga merupakan pegangan dalam pelaksanaan sensor diri, sesuai dengan tujuan dan fungsi media massa. Setiap wartawan pada hakikatnya memiliki standar profesi dan model karir yang dapat mereka atur sendiri. Ia benar-benar ingin menjadi wartawan profesional, wartawan amplop, wartawan bodreks. Namun, bagi wartawan umumnya, sebenarnya pegangan moral merupakan alasan kuat untuk menggeluti profesi ini. Ada sembilan elemen yang harus dipenuhi oleh wartawan dalam melaksanakan kegiatan jurnalistik secara profesional yakni sebagai berikut: a) wajib menegakkan kebenaran, b) loyal pada masyarakat, c) sebagai forum publik, d) disiplin dalam verifikasi liputan, e) menjaga kebebasan pers dari berbagai tekanan setiap liputan, f) pengawas independen terhadai berbagai bentuk kekuasaan, g) sajikan berita yang signifikan dan relevan, h) menyediakan berita yang komprehensif dan proporsional, h) mempertimbangkan kata hati atau hati nurani (Kovach\&Rosenstiel, 2001: 12-13).

Dari uraian di atas dapat diringkas bahwa self censorship merupakan elemen utama dalam sistem pers tanggungjawab sosial, karena wartawan harus mempertimbangkan semua langkah kegiatannya untuk masyarakat.

\section{Etika pers dan Kotak Potter}

Konsep etika pers berkembang seiring dengan profesi jurnalistik itu sendiri. Kode etik media adalah pedoman yang menjadi pegangan wartawan, tetapi seringkali kurang memadai ketika berhadapan dengan persoalan moral yang sulit. Hal ini karena posisi wartawan dengan lima kewajiban yang melekat pada dirinya sendiri, yakni kewajiban kepada diri sendiri, khalayak, atasan, profesi dan masyarakat Ini semua berhubungan dengan tuntutan media yang berkualitas yang pada gilirannya akan terrefleksi pada kebebasan pers itu sendiri. Kuncinya adalah kejujuran dalam melaksanakan tugas termasuk dalam peliputan dan investigasi. Menurut Belsey\&Chadwick (2005: 10-11) asumsi kode etik bukan sekadar kode etik itu sendiri secara harfiah yang memuat berbagai sanksi, bukan juga sejumlah aturan yang harus dipatuhi, tapi lebih merupakan prinsip atau komitmen mengenai baik-buruk atau salah-benar dalam masalah kemanusiaan yang dapat diterapkan dalam liputan yang objektif dan imparsial. Komitmen terhadap informasi berkualitas justru merupakan hakikat etika pers itu sendiri.

Kode etik media massa tidak dapat mengantipisipasi semua persoalan moral, namun di sisi lain sering terjadi ketidakkonsistenan dalam menerapkan prinsip moral yang sudah ditetapkan. Ralph Potter, profesor Harvard Divinity School, menyusun model empat kuadran untuk menguji problem etika yang disebut Kotak Potter, yang masing-masing memuat satu kategori pertanyaan (Vivian, 2008: 630-634). Kategori ini dapat membantu menjelaskan isu dan menghasilkan pandangan moral sebagai pegangan self censorship yang dapat dibenarkan. Berikut ini empat kuadran dari Kotak Potter, yakni: 1) kuadran situasi (situation); fakta atau 
isu yang ditentukan lebih dulu dibahas. Di sini tahapan keputusan dalam pemilihan isu untuk disiarkan media. Keputusan pada tahapan ini lebih bersifat redaksional, apakah sudah layak siar, di samping memperhatikan agenda media dan kepentingan masyarakat; 2) kuadran nilai (values): jika keputusan pada kuadran pertama telah disetujui, maka editor dan reporter mengidentifikasi nilai dan manfaat yang mendasari semua pilihan yang tersedia. Pada kuadran ini proses dilakukan dengan menyusun nilai positif dan negatif terhadap isu yang disiakan tersebut.; 3) kuadran prinsip (principles): untuk lebih menguatkan nilai pada kuadran 3 untuk kepentingan publik. Di sini berlaku pertimbangan sangat mendasar yakni loyalitas pada masyarakat (citizens) ; 4) kuadran loyalitas (loyalities): di sini pertimbangan adalah untuk memenuhi berbagai kepentingan, apakah pemberitaan itu untuk memenuhi kepentingan masyarakat, editor, pemilik modal atau untuk diri sendiri.

Kotak Potter tidak menyediakan jawaban, tapi hanya sebuah proses untuk mengkaji elemen elemen utama dalam persoalan etika dan self censorship. Hal ini karena Kotak Potter berfokus pada aspek moral, misal penyebutan nama korban perkosaan apakah bijak jika khalayak justru tersinggung sehingga mereka akhirnya tidak mau lagi membeli koran tersebut. Dengan munculnya berbagai efek yang tidak diinginkan dari isi media, seperti tayangan kekerasan di TV terhadap anak-anak, maka etika media dan self censorship menjadi pegangan wartawan dalam memilah-milah informasi yang disajikan di media sesuai dengan fungsi media massa. Apalagi, banyak isu sensitif yang dapat menjebak wartawan dengan alasan untuk kepentingan media atau tuntutan masyarakat. (Perry, 2002: 221)

\section{Kebebasan; Antara Nasionalisme dan Keperpihakan Media}

Media massa memiliki keterbatasan dalam menyajikan seluruh realitas sosial sehingga ada proses seleksi saat para editor sebagai gatekeeper memilih berita-berita mana saja yang akan dimuat atau tidak. Pemilihan ini jelas sangat subjektif dan bergantung pada misi, visi, nilai, atau ideologi yang ingin disampaikan media massa. Ketika media menyelekasi pemuatan berita, media itu telah berpihak kepada suatu nilai. Dalam konteks ini, media akan berada dalam tiga kemungkinan, yaitu apakah media cenderung berafeksi positif, netral, atau negatif. Keberpihakan yang paling mendasar terhadap suatu objek adalah perasaan mendukung (favourable) maupun perasaan tidak mendukung (unfavourable).

Kasus sengketa wilayah antara Indonesia dengan Malaysia atas wilayah Ambalat beberapa tahun lalu, tepatnya pada tahun 2005 menjadi contoh sempurna bagaimana wacana keberpihakan media di Indonesia dalam memberitakan konflik politik antarnegara. Bumbubumbu nasionalisme dan patriotisme memenuhi ruang-ruang berita media Indonesia. Setelah kasus Ambalat, memanasnya hubungan politik Indonesia-Malaysia kembali terjadi beberapa kali karena berbagai sebab. Namun, konflik tersebut juga cepat menguap seiring dengan bergantinya isu-isu seksi lainnya yang menggeser perhatian media.

Garis depan perbatasan Indonesia dan Malaysia, yaitu wilayah perairan seluas lapangan sepakbola bernama Karang Unarang, menjadi objek tindakan saling klaim oleh masing-masing negara. Indonesia mengatakan dengan tegas bahwa wilayah tersebut- juga Ambalat-merupakan bagian dari kepulauan Indonesia, berdasarkan peta warisan kolonial. Malaysia juga tak mau kalah, dengan mengatakan bahwa peta tersebut sudah tidak up to date, dan yang lebih aktual adalah peta versi baru buatan Inggris. Dengan patokan batas maritim tersebut, Ambalat pun dianggap sebagai bagian dari wilayah Malaysia (TEMPO, 20 Maret 2005). 
Munculnya kasus Ambalat ini memancing emosi bangsa Indonesia bahwa kedaulatan negara bukan hanya urusan negara. Berbagai aksi menentang Malaysia kian ramai digelar. Suasana panas semakin menjadi karena di sejumlah kota di Indonesia mendadak berjangkit sentimen anti-Malaysia. Sejumlah posko "Ganyang Malaysia" berdiri di berbagai daerah, bahkan dengan mengusung yel-yel rela mati untuk Indonesia, jika memang perang militer harus terjadi.

Di satu sisi, bangkitnya semangat nasionalisme dalam diri masyarakat Indonesia, sedikit banyak, dipengaruhi oleh hasil pemberitaan media. Lazimnya ketika negara sedang dilanda konflik bilateral, apalagi yang menyangkut dengan kedaulatan negara masing-masing, seluruh elemen warganegara tergerak untuk membangkitkan semangat kebangsaannya. Begitu pula dengan para pelaku media. Perasaan memiliki (sense of belonging) bisa menjadi faktor yang cukup memengaruhi cara para jurnalis memaknai sebuah peristiwa, untuk kemudian merekonstruksikannya dalam bentuk berita. Fitaha (2012) dalam penelitiannya tentang Kebebasan Pers dalam Konteks Hubungan Malaysia dan Indonesia menghasilkan kesimpulan bahwa dalam konteks pelaporan berita mengenai Ambalat,salah satu media harian Malaysia (Berita Harian) lebih sering memaparkan berita yang mengarah kepada upaya perpaduan negara serumpun. Sedangkan media di Indonesia (Harian Kompas) memiliki kelebihan dalam menampung berbagai pandangan kritis masyarakat tersebut isu mengenai Ambalat.

Ada semacam dilema dalam diri jurnalis Indonesia. Jika begitu saja membela negara dan tidak memberikan berita dengan berimbang, sama saja mereka mengkhianati konsepsi keadilan dan keseimbangan berita dalam jurnalisme profesional yang sudah dianut sekian lama. Sementara jika tidak, ada semacam rasa bersalah karena dianggap tidak setia dan loyal pada negara. Ihwal inilah yang memengaruhi pegiat media dalam membentuk wacana dan opini publik ketika melakukan pemberitaan.

Ditambah lagi dengan konteks historis Indonesia yang pernah berkonflik dengan Malaysia, dan gerakan anti-Malaysia juga lahir dengan nama yang sama. Kasus Ambalat seakan membuka memori warga kedua negara bahwa sebelumnya mereka pernah berseteru dan menimbulkan sentimen-sentimen sejarah. Konteks historis ini hanya satu dari sekian banyak faktor, yang membuat pelaku media di Indonesia menambahkan bumbu-bumbu patriotisme ke dalam beritanya. Maka tak heran, jika istilah-istilah yang bisa menimbulkan sebuah opini bahwa "Malaysia adalah musuh", bertebaran di ruang-ruang berita media massa cetak. Sebut saja TEMPO (edisi 14-20 Maret 2005, hal.28) yang menuliskan "...kapal Malaysia yang suka memancing geram.", atau Suara Merdeka (edisi 14 Maret 2005) yang menulis “...Malaysia sebagai negara tetangga yang mulai menggerogoti keutuhan wilayah Republik Indonesia, terutama di Ambalat." (cetak tebal oleh penulis). Hal ini cukup menegaskan adanya "campur tangan" rasa kebangsaan individu dalam menulis sebuah berita.

Meski seringkali terdapat faktor "dorongan"-secara langsung maupun tak langsungdari pemerintah untuk membela negara atau posisi pemerintah yang tidak tegas dalam berdiplomasi, namun terlibatnya semangat nasionalisme seorang jurnalis sedikit banyak memengaruhi objektivitas dalam menulis berita. Alasan-alasan seperti menjaga citra bangsa di dunia internasional, atau dalam konteks untuk tetap menjaga kedaulatan negara, pembentukan opini tentu terjadi di masyarakat. Pada titik ini, media berhasil mengeluarkan kekuatannya dalam memengaruhi wacana yang berkembang di ruang publik. 
Dalam kasus peliputan berita tentang Ambalat misalnya, terdapat indikasi adanya kandungan ideologi kebangsaan dalam penulisan berita. Sekilas praktik jurnalisme ini tidaklah menjadi masalah. Tapi, dengan praktik seperti itu, berita tidak lagi berada di tengah-tengah dan tidak berpihak. Malah, semakin lama wartawan ditengarai potensial untuk menyebarkan berita bohong, dengan tujuan menjaga citra bangsa. Ideologi kebangsaan atau nasionalisme, adalah sebuah paham yang pada intinya mensyaratkan kecintaan yang besar pada tanah air, etnis, dan kelompok. Peter Alter (1989: 5) menyebut bahwa nasionalisme juga seringkali memberikan harapan tentang kebebasan dan tatanan sosial yang adil tanpa diskriminasi. Sebab, satu sama lain anggota sebuah kelompok atau suku bangsa memiliki perasaan sama dan kesetaraan, termasuk di kalangan jurnalis.

Praktik jurnalisme yang demikian ini, sebenarnya pernah diterapkan oleh para jurnalis Amerika Serikat, khususnya pasca peristiwa pemboman gedung World Trade Center tanggal 11 September 2001. Ada sebuah ideologi patriotis yang terkandung dalam berita-berita yang dimunculkan. Saat itu, dalam pemberitaan invasi AS ke Irak, penggunaan kata "kita" - yang menunjuk pada tentara AS - dan kata "mereka" - yang merujuk pada tentara lawan sangat mudah ditemukan dalam berbagai berita di media AS. Selain karena perasaan senasib sepenanggungan dengan para korban, terdapat tekanan besar dari pemerintah, untuk menyajikan berita yang mendukung Amerika.

Negara seolah mewajibkan para pelaku media untuk membela negaranya. Jika tidak, beban psikologis sebagai pengkhianat bangsa akan membayangi begitu saja. Maka, bisa dibilang, fanatisme kebangsaan dalam rekonstruksi berita di media massa cetak terjadi karena berbagai faktor. Dan meskipun jurnalisme patriotik tersebut dimaksudkan untuk memberi pembelaan kepada negara, pada akhirnya prinsip-prinsip jurnalisme profesional menjadi ternegasikan. Selain karena perasaan senasib sepenanggungan dengan para korban, terdapat tekanan besar dari pemerintah, untuk menyajikan berita yang mendukung Amerika.

\section{Kebebasan atau Kebablasan Pers?}

Bagaimanapun kecilnya sebuah kontroversi, jika diliput dan diberitakan oleh massa akan berubah menjadi konflik yang lebih besar. Paling tidak keberadaannya akan memiliki legitimasi. Demikian ungkap Tichenor, $d k k$., dalam bukunya Community Conflict and the Press (1980). Tanpa media massa, konflik akan menjadi berita kecil yang terbatas daya jangkaunya. Lebih lanjut Tichenor menilai, efek psikologis pemberitaan konflik jauh melebihi apa yang bisa dicapai oleh konflik itu sendiri. Media menjadi sarana percepatan sebuah topik menuju kesadaran dan kepentingan masyarakat yang lebih luas (Tichenor, $d k k ., 1980: 119$ ).

Pemberitaan konflik melalui media selalu bersinggungan dengan dua sisi: mempertajam atau sebaliknya, mereduksi konflik. Dalam kaitan ini, setidaknya ada tiga posisi media dalam memberitakan konflik. Pertama, media sebagai issue intensifier: media berposisi memunculkan konflik kemudian mempertajamnya. Dalam posisi ini, media mem-blow up realitas menjadi isu sehingga seluruh dimensi konflik menjadi transparan. Kedua, media sebagai conflict diminisher, yakni menenggelamkan suatu isu atau konflik. Secara sengaja media meniadakan isu tersebut, terutama bila menyangkut kepentingan media bersangkutan, entah kepentingan ideologis atau pragmatis. Ketiga, media berfungsi sebagai pengarah konflik (conflict resolution), yakni menjadi mediator dengan menampilkan isu dari berbagai perspektif serta mengarahkan pihak yang bertikai pada penyelesaian konflik. Lewat pemberitaan di 
media, pihak yang terlibat diharapkan memahami sudut pandang pihak lain, mengatasi prasangka dan kecurigaan, serta mengevaluasi ulang sikap apriori yang semula terbentuk.

Melihat isi sebuah media adalah melihat bagaimana pembentukan wacana sosial di dalamnya, maka sama saja dengan melihat bagaimana media merepresentasikan dunia ini, melalui simbol-simbol apa media menyebarluaskan sebuah wacana kepada masyarakat, serta hubungan-hubungan apa yang terbentuk. Itu semua, direfleksikan dalam berita yang dihasilkan oleh media tersebut. Proses pembentukan wacana oleh media, ternyata juga dipengaruhi oleh pihak-pihak yang "memegang" media itu sendiri. Pemahaman ini berlandaskan pada pandangan paradigma kritis. Everett M. Rogers (dalam Eriyanto, 2001: 23) menyebutkan bahwa dalam paradigma ini media dipandang sebagai entitas yang tidak bebas nilai, melainkan sangat rentan akan penguasan oleh pihak dominan, yang dipenuhi oleh prasangka, retorika, dan propaganda).

Memahami berita, sama saja dengan memahami sebuah produk teks. Ketika memahami teks ini, audiens dapat melihat bagaimana realitas empirik ditampilkan oleh berita. Perlu diingat, bahwa berita, adalah sebuah wacana yang sengaja dibangun oleh media. Ketika menyajikan sebuah berita, media dipengaruhi oleh seperangkat nilai dan ideologi yang dianut, sehingga media memiliki tendensi-tendensi tertentu, yang pada akhirnya disebarluaskan kepada publik.

Paradigma kritis memandang berita tidak hanya serangkaian kalimat dan serentetan paragraf dalam teks, melainkan berita sesungguhnya diliputi sejumlah variabel ketika diproduksi. Faktor-faktor itu adalah fakta, posisi media yang bersangkutan, posisi wartawan yang meliput beritanya, serta hasil liputan - yang berkorelasi kuat dengan kemampuan kognitif wartawan menerjemahkan sebuah peristiwa. Dan bahasa, yang menjadi media penyampaian pesan berita, merupakan representasi dari dunia nyata. Karenanya, peran bahasa juga sangat penting dalam pembentukan wacana itu sendiri.

Berita, yang notabene memiliki banyak dimensi wacana yang menarik untuk diteliti, harus dibaca dan dipahami dalam sebuah situasi sosial yang meliputi norma, nilai, tujuan, serta kepentingan bersama. Oleh karena itu, bagaimana sebuah berita dipahami harus selalu diletakkan dalam konteks sosial dan system politik yang ada.

Menurut Aart van Zoest (1991, dalam Sobur, 2002: 60), sebuah teks tak pernah lepas dari ideologi. Ia juga memiliki kemampuan untuk memanipulasi pembaca ke arah suatu ideologi. Sebuah ideologi, menurut Eriyanto (2001: 13), adalah suatu konsep sentral dalam analisis wacana yang bersifat kritis. Sebab, teks, percakapan, dan lainnya adalah bentuk dari praktik ideologi atau pencerminan dari ideologi tertentu Ini artinya, suatu berita sangat mungkin merepresentasikan ideologi yang diusung serta untuk memenuhi kepentingan berbagai pihak.

Lalu dengan melihat perbedaan dasar paradigma dan perspektif jurnalisme, bagaimana seharusnya wartawan bersikap dan berpihak dalam meliput dan memberitakan konflik? Dimulai dari kewajiban wartawan memahami dan mempraktikkan jurnalisme profesional dengan menepati prinsip objektivitas pemberitaan. Kemudian setelah standar dasar jurnalisme tersebut terpenuhi, wartawan hendaknya menerapkan jurnalisme damai dalam setiap pemberitaan konflik yang ditulisnya sehingga kontroversi tidak berlangsung berlarut-larut tanpa arah penyelesaian. Selanjutnya, agar berita yang disajikan kepada pembaca mampu mengungkap realitas konflik secara komprehensif, wartawan juga perlu bekerja kreatif dengan teknik peliputan ala jurnalisme investigasi. Sebagai titik puncak dari "perjalanan menentukan keberpihakan" ini, terutama dalam pemberitaan mengenai kasus-kasus yang melibatkan 
kepentingan masyarakat luas, jurnalis berkewajiban menerapkan jurnalisme publik sebagai bentuk pertanggungjawaban kepada masyarakat.

Menurut konsepsi "baku" etika jurnalisme, dalam pemberitaan konflik, media yang diwakili oleh jurnalis dituntut berada dalam "situasi tengah" antara pihak-pihak yang terlibat konflik. Beberapa pandangan meneguhkan bahwa tugas jurnalis yang utama adalah menjalankan profesi secara independen dengan mengikuti kaidah-kaidah jurnalistik. Jurnalis juga tidak boleh memihak salah satu pihak atau hanya menyuarakan pihak tertentu dan menafikan keberadaan pihak lain. Karena itu jurnalis tidak boleh membawa kepentingan salah satu pihak yang bertikai. Semua pihak memiliki hak yang sama atas akses informasi.

Pendek kata, peran ideal seorang jurnalis dalam memberitakan konflik adalah menjalankan tugas profesional. Saat bertugas, jurnalis memiliki komitmen untuk mencari berita dan menginformasikannya kepada pembaca sesuai standar teknis dan etika jurnalistik. Untuk memenuhi tuntutan profesionalisme itu, sekali lagi jurnalis harus selalu menjaga sikap netral, objektif, berimbang, akurat, dan benar sehingga jurnalis harus berada dalam posisi independen dan tidak memihak (Burns, 2002: 22-24).

Pandangan-pandangan normatif tentang "profesionalisme" wartawan kemudian dikritik oleh Kovach dan Rosenstiel (2004) dan Charity (1995). Kovach mengungkapkan, komitmen kepada warga (citizen) yang dimiliki jurnalis seharusnya lebih besar ketimbang egoisme profesional. Artinya, tugas utama seorang jurnalis adalah bertanggung jawab kepada kepentingan warga. Kesetiaan pada warga ini disebut Kovach sebagai independensi jurnalistik yang sesungguhnya (Kovach \& Rosestiel, 2004: 59). Dalam ranah kesadaran moral yang lebih luas, jurnalis diharapkan memiliki kepekaan sosial sehingga mendorong terciptanya arah penyelesaian konflik melalui berita yang ditulisnya. Jurnalis bekerja tidak sekadar memberitakan tanpa memberi alternatif bagi penyelesaian persoalan yang terjadi di ruang public

\section{PENUTUP}

Dalam kehidupan masyarakat, perbedaan dan persamaan pandangan merupakan bentuk dari sebuah kewajaran dalam berkehidupan. Hal ini juga berlaku dalam tubuh media massa, termasuk pers di negara-negara yang meskipun secara geografis sangat berdekatan. Dengan berbagai latar peristiwa yang disoroti, kajian berfokus pada Indonesia dan Malaysia yang selalu menghadirkan hal-hal unik. Secara faktual, meskipun dalam geografis yang berdekatan, sejumlah perbedaan selalu mengemuka di antara keduanya. Dalam perjalanan waktu, kontroversi, ketegangan dan konflik mewarnai hubungan kedua negara sejak keduanya menjalin kontak yang berjalan pararel pula dnegan persamaan pandangan kesepakatan dan kedekatan secara harmonis atas dasar kepentingan masing-masing.

Dalam kasus peliputan berita tentang Ambalat misalnya, terdapat indikasi adanya kandungan ideologi kebangsaan dalam penulisan berita. Sekilas praktik jurnalisme ini tidaklah menjadi masalah. Tapi, dengan praktik seperti itu, berita tidak lagi berada di tengah-tengah dan tidak berpihak. Malah, semakin lama wartawan ditengarai potensial untuk menyebarkan berita bohong, dengan tujuan menjaga citra bangsa. Ideologi kebangsaan atau nasionalisme adalah sebuah paham yang pada intinya mensyaratkan kecintaan yang besar pada tanah air, etnis, dan kelompok. Nasionalisme juga seringkali memberikan harapan tentang kebebasan dan tatanan 
sosial yang adil tanpa diskriminasi. Sebab, satu sama lain anggota sebuah kelompok atau suku bangsa memiliki perasaan sama dan kesetaraan, termasuk di kalangan jurnalis.

Evaluasi terhadap liputan pers Malaysia dan Indonesia pun tak berbeda dengan hubungan kedua Negara tersebut. Pada titik tertentu liputan pers Indonesia sering dikecam dengan tidak sesuai fakta, tidak bebas dan lebih sebagai corong pemerintah. Tapi di sisi lain, pada kurun waktu tertentu hubungan dalam dunia informasi pers Malaysia dan Indonesia berjalan harmonis. Saling membantu dan saling mengevaluasi. Dengan demikian, kebebasan pers dalam konteks Negara bertetangga di satu sisi dapat menjadi api dalam sekam yang berwujud kepada konflik bilateral sehingga masing-masing pers kehilangan asas keberimbangannya. Namun di sisi yang lain, kebebasan pers juga - secara penerimaan rasionaliasai dan opini publik, persamaan dan perbedaan itu dapatlah diterima. Jika urusan tersebut kemudian dikembalikan pada urusan kebenaran dan keberimbangan maka hal ini kiranya bisa membuka peluang lain untuk mendiskusikan lebih dalam lagi tentang liputan pers kedua Negara teresebut.

\section{DAFTAR PUSTAKA}

Abdul Latiff Abu Bakar. (2009). Hubungan Malaysia-Indonesia melalui media cetak: satu tafsiran. Makalah dipresentasikan dalam Seminar Hubungan Indonesia-Malaysia 2009, Kuala Lumpur, Malaysia.

Belsey, Andrew\&Ruth Chadwick. (2005). Ethical Issues in Journalism and The Media. Routledge.

Fitaha Aini. 2012. Kebebasan Pers dalam Konteks Hubungan Indonesia-Malaysia. "Studi Pada Berita Harian (Malaysia) dan Kompas (Indonesia). Aspikom. UPN Veteran Yogyakarta.

Hallin, Daniel C. dan Mancini, Paolo (2004). Comparing Media System. "Three Models of Media and Politics. Communication, Society and Politics. Cambridge University Press.

Hardt, Hanno (1988). Comparative Media Research; The World According to America, "Critical Studies in Mass Communication".

Hardt, Hanno (1997). Social Theory of The Press; Early German and American Perspective. Beverly Hills; Sage Publisher.

Haryatmoko. 2007. Etika Komunikasi: Manipulasi Media, Kekerasan dan Pornografi. Jakarta: Kanisius.

Hazel, Kathryn-Jane (2001). The Media and Nationalism in Quebec; A Complex Relationship. "Journalism Studies 2 (1): 93-107

Kovach, Bil \& Tom Rosenstiel. (2001). The Elements of Journalism. What News People Should Know and The Public Should Expect. Three Rivers Press, New York. 
Lesmana, Tjipta. 2005. Pencemaran Nama Baik dan Kebebasan Pers Antara Indonesia dan Amerika. Jakarta: Erwin-Rika Press.

Mohd Safar Hasim. (2005). Akhbar di Malaysia; Antara kebebasan dengan tanggung jawab. Bangi: Universiti Kebangsaan Malaysia.

Mohd. Safar Hasim. (1996). Mahathir dan Akhbar. Kuala Lumpur: Utusan Publications \& Distributors. Smith, 1997 New York

Perry, David K. (2002). Theory and Research in Mass Communication. Context and Consequences.

Suwardi, Harsono. 2007. Bahan Kuliah: Media \& Government Relations. Jakarta: Pascasarjan FISIP UI.

Vivian, John. (2008). Teori Komunikasi Massa, terjemahan. Jakarta, Kencana Group

Situs Web

http://rsf.org/index2014/en-index2014.php Diakses Pada 20 Juni 2014. 